\title{
$\alpha$-AMYLASE INHIBITION AND ELECTROCHEMICAL BEHAVIOR OF SOME OXOVANADIUM (IV) COMPLEXES OF L-AMINO ACIDS
}

\author{
MAHENDRA KUMAR MISHRA ${ }^{1 *}$, RUCHITA TRIPATHI ${ }^{2}$, PANDEYA KB ${ }^{3}$, TRIPATHI IP ${ }^{4}$
}

${ }^{1}$ Department of Biological Sciences, Mahatma Gandhi Chitrakoot Gramodaya Vishwavidyalaya, Chitrakoot, Satna, Madhya Pradesh, India. ${ }^{2}$ Department of Biotechnology, Govt. T. R. S. College, Rewa Madhya Pradesh, India. ${ }^{3}$ Department of Physical Sciences, Mahatma Gandhi Chitrakoot Gramodaya Vishwavidyalaya, Chitrakoot, Satna, Madhya Pradesh, India. ${ }^{4}$ Department of Faculty of Science and Environment, Mahatma Gandhi Chitrakoot Gramodaya Vishwavidyalaya, Chitrakoot, Satna, Madhya Pradesh, India.

Email: mahigene8611@gmail.com

Received: 09 March 2018, Revised and Accepted: 27 April 2018

ABSTRACT

Objective: Diabetes is complex metabolic disease having a symptom of hyperglycemia. Oxovanadium (IV) and l-amino acids are used to normalize the hyperglycemic condition. The aim of this study was to screen the $\alpha$-amylase inhibitory activity of l-amino acids, their oxovanadium (IV) complexes, and electrochemical activity of oxovanadium (IV) complexes.

Methods: All the oxovanadium (IV) complexes were synthesized according to the solubility of l-amino acids; the molar ratio of metal to l-amino acid was 1:2. The synthesized oxovanadium (IV) complexes were examined for their electrochemical behavior in $0.01 \mathrm{M}$ sodium perchlorate solution. Further, the oxovanadium (IV) complexes of l-amino acids and l-amino acids were screened for their $\alpha$-amylase inhibitory activity using spectrophotometric assay system.

Results: The synthesized complexes were divided into four groups according to nature of amino acids. Entire complexes show simple irreversible wave for VO redox couples in $-900-50 \mathrm{mV}$ potential range and scan rate was $300 \mathrm{mV} / \mathrm{S}$. All the complexes and l-amino acids were screened for their $\alpha$-amylase inhibitory activity. L-Histidine and their oxovanadium (IV) complex show the minimum IC ${ }_{50}$ value, i.e. $4199.05 \mu \mathrm{M}$ and $101.015 \mu \mathrm{M}$, respectively, in their respective groups.

Conclusion: The data obtained from our study, it reveals that the entire oxovanadium (IV) complexes are an irreversible wave for VO redox system and the l-histidine and its oxovanadium (IV) complex is the most potent inhibitor for the $\alpha$-amylase. Further, the complexes show minimum IC ${ }_{50}$ value on comparing their respective ligands due to the interaction of Vanadyl complex to the enzyme, at the sixth vacant position of Vanadyl complex

Keywords: Diabetes mellitus, Oxovanadium (IV) complexes, l-Amino acids, $\alpha$-amylase inhibition, Cyclic voltammeter.

(C) 2018 The Authors. Published by Innovare Academic Sciences Pvt Ltd. This is an open access article under the CC BY license (http://creativecommons. org/licenses/by/4. 0/) DOI: http://dx.doi.org/10.22159/ajpcr.2018.v11i8.25800

\section{INTRODUCTION}

During the development of diabetes, the cellular balance of carbohydrate and lipid metabolism is affected by improper regulation. This improper regulation of carbohydrate leads to elevated post-prandial blood glucose level. Prolonged imbalance of carbohydrate interrupts the homeostasis of various physiological systems of the body, which leading to the onset of diabetes complication $[1,2]$

Abnormal high blood glucose level in periphery fluid can leads to a number of serious consequences, including nerve and blood vessel damage, heart disease, kidney disease, stroke, and blindness [3-5]. The manifestation of pancreatic $\beta$-cell impairment and a gradual loss of cellular responsiveness of insulin cause Type II diabetes. Since type II diabetes cases are associated with insulin insensitivity, high levels of insulin linked to obesity [6], and now oral therapeutic drugs are preferred to lower or normalize blood glucose level by physicians.

The digestion of starch is a multistep process that begins in the oral cavity with the hydrolysis of insoluble starch polymers into shorter oligomers by salivary $\alpha$-amylase [7-9]. On reaching the small intestine, pancreatic $\alpha$-amylase provides more extensive hydrolysis of starch. The resulting mixture then passes into the brush border of the small intestine where it is processed into glucose by the resident enzymes $\alpha$-glucosidases maltase/glucoamylase and sucrase/isomaltase $[8,10]$.

For normalizing the blood glucose level in peripheral fluids can be accomplished by oral antidiabetic drugs which control the influx of glucose into the bloodstream from the liver and the gastrointestinal track, these two strategic points for design new drugs [11]. Most therapeutic oral drugs currently in use inhibit the enzymes of gastrointestinal track. Further, most of the drugs in use are centered to inhibit the $\alpha$-glucosidases since this approach also prevented the hydrolysis of common dietary sugars such as sucrose into glucose while blocking the hydrolysis of starch-derived oligosaccharides [11-13]. The $\alpha$-glucosidase inhibitors miglitol, voglibose, and acarbose are iminosugar based molecules that are used in clinic practice, and unfortunately, all are associated with side effects ranging from diarrhea to hepatotoxicity $[14,15]$. Due to the natural consequences of displacement of di- and trisaccharides to the lower gut leads to osmoticinduced diarrhea and anaerobic fermentation [15]. $\alpha$-amylase is active within the lumen of the duodenum thus, orally administered inhibitors that stay within the gastrointestinal tract will be optimally localized for amylase inhibition and will be less likely to cause undesirable side effects.

To inhibit the $\alpha$-amylase, we are intended to screen the inhibitory activity of oxovanadium (IV) complexes with l-amino acids and solely l-amino acids for the sake of comparison. The agenda behind to choose oxovandium(IV), l-amino acids and their respective complexes for screening the $\alpha$-amylase inhibition and electrochemical activity because we have been previously reported their antioxidant activity and found good scavenger agents[16,17].

Hence, this study sought to investigate the inhibitory effect of amino acids and their oxovanadium (IV) complexes on key enzyme linked to 
diabetes ( $\alpha$-amylase) as well as assessing the electrochemical behavior of these complexes.

\section{METHODS}

\section{Chemicals}

Chemicals and reagents used such as porcine pancreatic $\alpha$-amylase, dinitrosalicylic acid, p-nitrophenyl- $\alpha$-D-glucopyranoside, sodium chloride, and sodium diphosphate were procured from SRL, India. Acarbose was sourced from Sigma-Aldrich. Sodium carbonate, methanol, potassium acetate, and starch were of analytical grade while the water was glass distilled.

\section{Synthesis of complexes}

Synthesis of oxovanadium (IV) complexes was categorized according to the solubility of amino acids.

\section{Synthesis of complexes at 7-8 pH}

A $1 \mathrm{mM}$ of amino acid (Glycine, Valine, Alanine, Proline, Serine, Histidine, Arginine, Lysine, Threonine) was dissolved in $30 \mathrm{ml}$ water and a transparent solution was obtained. In above solution $0.5 \mathrm{mM}$ of $\mathrm{VOSO}_{4} \cdot 5 \mathrm{H}_{2} \mathrm{O}$ was mixed drop by drop with continuous stirring, blue/ deep blue solutions were obtained. The excess solution was removed by evaporation to get the complex precipitate out on cooling.

\section{Synthesis of complexes at 10-12 pH}

A mixture of $1 \mathrm{mM}$ of amino acids (methionine, asparagine, tyrosine, glutamic acid, glutamine, aspartic acid, and phenylalanine) and $1 \mathrm{mM}$ of sodium acetate was dissolved in water followed by addition of $0.5 \mathrm{mM}$ Vanadyl sulfate. The solution was stirred for $4 \mathrm{~h}$. The excess solution was removed by evaporation to get the complex precipitate out on cooling.

\section{Synthesis of complexes at 13-14 pH}

A mixture of $1 \mathrm{mM}$ of amino acids (leucine, isoleucine, and tryptophan), except cystine $(0.5 \mathrm{mM})$ and 1 mole of sodium hydroxide was dissolved in water followed by addition of 0.5 -mole Vanadyl sulfate. The solution was stirred for $4 \mathrm{~h}$. The excess solution was removed by evaporation to get the complex precipitate out on cooling.

\section{Cyclic voltammeter}

The cyclic voltammetric measurements were carried out with a BAS instrument having an electrochemical cell with a three-electrode system. The auxiliary electrode was an $\mathrm{Ag} / \mathrm{AgCl}_{2}$. Glassy carbon was used as a working electrode, while a platinum wire electrode used as a reference electrode. The concentrations of complexes were taken
$0.3 \mathrm{mg} / \mathrm{ml}$, dissolved in supporting electrolyte $10 \mathrm{ml}$ of $0.01 \mathrm{M}$ solution of sodium perchlorate $\left(\mathrm{NaClO}_{4}\right)$ solution.

\section{$\alpha$-amylase inhibition}

Pancreatic $\alpha$-amylase assay was adopted from Apostolidis and Lee [18], $500 \mu \mathrm{l}$ of different dilutions of test compounds and $500 \mu \mathrm{l}$ of $0.02 \mathrm{M}$ sodium phosphate buffer ( $\mathrm{pH} 6.9$ with $0.006 \mathrm{M}$ sodium chloride) containing $\alpha$-amylase solution $(0.5 \mathrm{mg} / \mathrm{mL})$ were incubated at $25^{\circ} \mathrm{C}$ for $10 \mathrm{~min}$. After pre-incubation, $500 \mu \mathrm{l}$ of $1 \%$ starch solution in $0.02 \mathrm{M}$ sodium phosphate buffer ( $\mathrm{pH} 6.9$ with $0.006 \mathrm{M}$ sodium chloride) was added to each tube. The reaction was incubated at $25^{\circ} \mathrm{C}$ for $10 \mathrm{~min}$. The reaction was stopped with $1 \mathrm{~mL}$ of DNS color reagent. The closed tubes were placed in a water bath $\left(85-90^{\circ} \mathrm{C}\right)$ for 10 min to develop color and left to cool room temperature. The reaction mixture was diluted with $10 \mathrm{ml}$ of distilled water absorbance $(540 \mathrm{~nm})$ was read spectrophotometrically. Percentage of inhibition was expressed in terms $\mu \mathrm{g} / \mathrm{ml}$.

\section{RESULTS}

Synthesis of complexes

All the oxovanadium (IV) complexes were synthesized as reported earlier [16].

Electrochemical behavior of oxovanadium (IV) complexes by CV Cyclic voltammetry is the most flexible electroanalytical technique for the study of electroactive species. The important parameters of a cyclic voltammogram are the magnitudes of the anodic peak current (ipa), cathodic peak current (ipc), anodic peak potential (Epa), and cathodic peak potential (Epc). The cyclic voltammogram of the oxovanadium (IV) complex, recorded in sodium perchlorate as supporting electrolyte. Fig. 1 voltammogram of $\mathrm{VO}+$ Valine shows one reduction peak Epc in cathodic direction which is assigned as follow $\mathrm{VO}^{\mathrm{IV}} \rightarrow \mathrm{VO}^{\mathrm{III}}$ at Epc $=-542 \mathrm{mV}$. The oxidation peak at $-360 \mathrm{mV}$ is due to irreversible oxidation of VO+Valine $\left(\mathrm{VO}^{\mathrm{III}} \rightarrow \mathrm{VO}^{\mathrm{IV}}\right)$. The number of electrons transferred and redox potential was obtained from the value of $\Delta \mathrm{Ep}=\mathrm{Epa-Epc}$ and $\mathrm{E}_{1 / 2=}(\mathrm{Epa}+\mathrm{Epc}) / 2$, respectively (Table 1) [23].

The electrochemical behaviors of all complexes have been studied by cyclic voltammetric techniques using a glassy carbon electrode in electrolyte in water under an inert atmosphere. All the complexes show simple irreversible wave for $\mathrm{VO}$ redox couples in -900-50 mV potential range and scan rate was $300 \mathrm{mV} / \mathrm{S}$. The voltammogram of VO-Valine shown in Fig. 1 and the parameters of all oxovanadium (IV) complexes are represented in Table 1.

Table 1: CV parameters of oxovanadium (IV) complexes

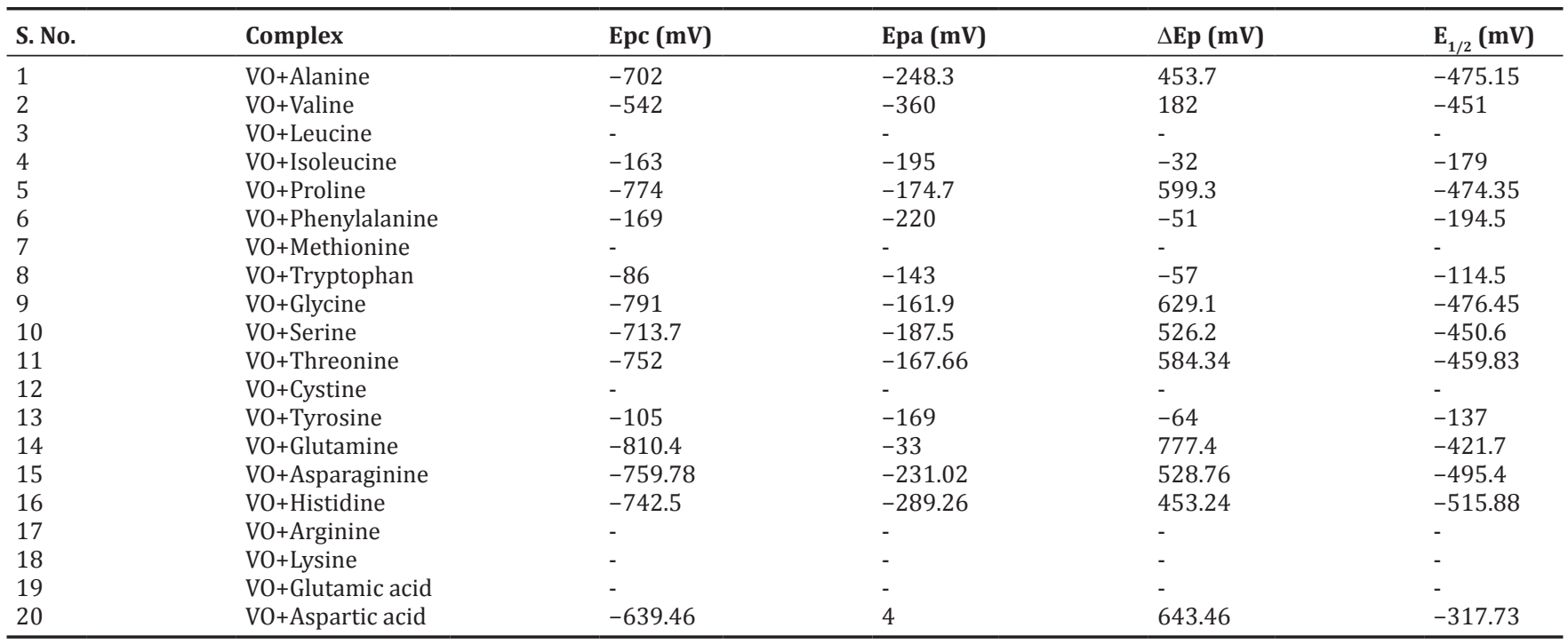




\section{$\alpha$-amylase inhibition}

$\alpha$-amylase inhibition data (percentage inhibition at 100 and $1000 \mu \mathrm{g} / \mathrm{ml}$ and IC $_{50}$ values) for oxovanadium (IV) complexes are presented in Table 2 in the same table the data of uncoordinated (free) ligands are also given for the sake of comparison. The results of inhibition of $\alpha$-amylase by oxovanadium (IV) complexes at various concentrations are also presented graphically in Figs 2-9.

A scrutiny of the $\mathrm{IC}_{50}$ data for inhibition of $\alpha$-amylase by the amino acids and their oxovanadium (IV) complexes yields the following valuable points:

1. Complexes show much higher inhibition potentials compared to the corresponding amino acids.

2. A plot of $\mathrm{IC}_{50}$ values for the complexes versus $\mathrm{IC}_{50}$ values for the corresponding amino acids yields a linear relationship with the exception of only few amino acids, namely glycine, valine, leucine, and isoleucine, Fig 10.

Figs. 2, 4, 6, and 8 represent the inhibition curve of $\alpha$ - amylase by oxovanadium (IV) complexes at various concentrations while Figs. 3, 5,7 , and 9 show the inhibition curve for $\alpha$ - amylase by l-amino acids at different concentrations. We have divided the amino acids into four groups according to nature of their side chains. Fig. 10 was plotted between the $\mathrm{IC}_{50}$ values of amino acid and their corresponding

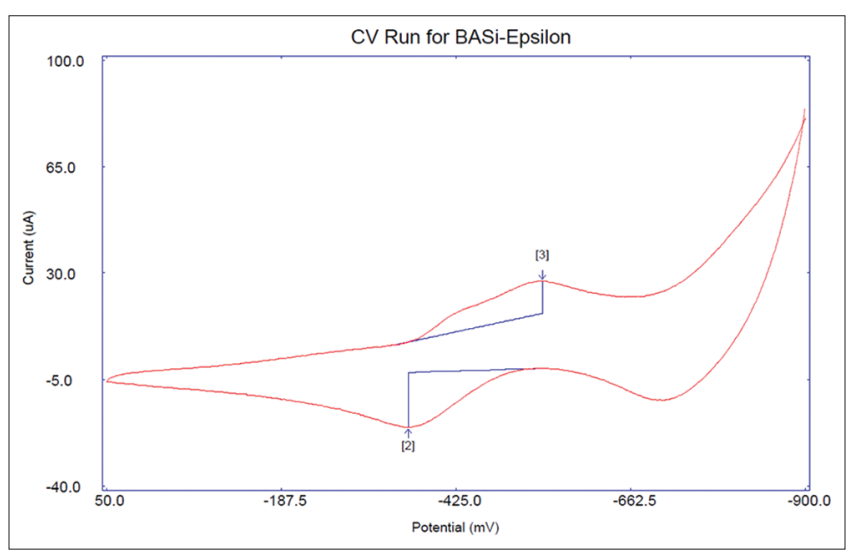

Fig. 1: Voltammogram of Vo+valine oxovanadium (IV) complexes, only 15 test samples except glycine, valine, leucine, and isoleucine and their respective oxovanadium (IV) complexes. The regression line was liner and the value of correlation coefficient was 0.81562 , the association between $\mathrm{IC}_{50}$ values was strongly positive [19].

Table 2 contains the $\mathrm{IC}_{50}$ values in $\mu \mathrm{g} / \mathrm{ml}$ and calculated $\mu \mathrm{M}$, calculating the exact $\mathrm{IC}_{50}$ value the curve was screen for their fitted model and function to achieve the equation of line. The entire curve falls in two model categories, i.e. exponential and sigmoidal. The nature of curve explains the interaction between inhibitor and substrate (enzyme). The oxovanadium (IV) complexes of threonine, cystine, tyrosine, glutamine, asparagine, lysine, histidine, arginine, glutamic acid, and aspartic acid and these amino acid shows the sigmoid curve nature of inhibition and leftover l-amino acids and their respective complexes show exponential nature of inhibition. The sigmoid nature of inhibition pattern describes that on increasing the concentration of inhibitor they resumes or inhibits the activity of enzyme more actively while at the same concentration inhibitors showing exponential nature inhibition shows less inhibition. Moreover, on increasing the concentration of inhibitor the sigmoid nature curve shows a saturation point, it means further addition of inhibitor does not affect the activity of substrate (enzyme).

Amino acid follows the following decreasing order of inhibition potential-

Histidine $\left(\mathrm{IC}_{50}=4199.05 \mu \mathrm{M}\right)>$ cystine $\left(\mathrm{IC}_{50}=4633.5 \mu \mathrm{M}\right)>$ tyrosine $\left(\mathrm{IC}_{50}=4726.47 \mu \mathrm{M}\right)$ >lysine $\quad\left(\mathrm{IC}_{50}=5052.17 \mu \mathrm{M}\right)$ >tryptophan $\left(\mathrm{IC}_{50}=5399.96 \mu \mathrm{M}\right)>$ arginine $\left(\mathrm{IC}_{50}=5792.69 \mu \mathrm{M}\right)>$ phenylalanine $\left(\mathrm{IC}_{50}=6190.7 \mu \mathrm{M}\right)>$ methionine $\left(\mathrm{IC}_{50}=6193.38 \mu \mathrm{M}\right)>$ glutamic acid $\left(\mathrm{IC}_{50}=6451.93 \mu \mathrm{M}\right) \quad>$ isoleucine $\left(\mathrm{IC}_{50}=6658.24 \mu \mathrm{M}\right) \quad$ glutamine $\left(\mathrm{IC}_{50}=6994.71 \mu \mathrm{M}\right)$ >asparagine $\left(\mathrm{IC}_{50}=7072.49 \mu \mathrm{M}\right)$ >aspartic acid $\left(\mathrm{IC}_{50}=7074.07 \mu \mathrm{M}\right)$ >threonine $\left(\mathrm{IC}_{50}=9550.65 \mu \mathrm{M}\right)>$ leucine $\left(\mathrm{IC}_{50}=10365.4 \mu \mathrm{M}\right)>$ valine $\left(\mathrm{IC}_{50}=11606.8 \mu \mathrm{M}\right)>$ serine $\left(\mathrm{IC}_{50}=12272.2\right.$ $\mu \mathrm{M})>$ proline $\left(\mathrm{IC}_{50}=13048 \mu \mathrm{M}\right)>$ alanine $\left(\mathrm{IC}_{50}=15499.1 \mu \mathrm{M}\right)>$ glycine $\left(\mathrm{IC}_{50}=25540.1 \mu \mathrm{M}\right)$.

While the order of amino acids for inhibition by oxovanadium (IV) complexes are-

Histidine $\left(\mathrm{IC}_{50}=101.015 \mu \mathrm{M}\right)>$ tyrosine $\left(\mathrm{IC}_{50}=125.868 \mu \mathrm{M}\right)>$ Cystine $\left(\mathrm{IC}_{50}=135.414 \mu \mathrm{M}\right)$ >tryptophan $\left(\mathrm{IC}_{50}=146.029 \mu \mathrm{M}\right)>$ methionine $\left(\mathrm{IC}_{50}=146.243 \mu \mathrm{M}\right)$ >arginine $\left(\mathrm{IC}_{50}=147.547 \mu \mathrm{M}\right)>$ phenylalanine $\left(\mathrm{IC}_{50}=162.832 \mu \mathrm{M}\right)$ >lysine $\left(\mathrm{IC}_{50}=164.706 \mu \mathrm{M}\right)>$ glutamic acid $\left(\mathrm{IC}_{50}=182.575 \mu \mathrm{M}\right) \quad>$ glutamine $\left(\mathrm{IC}_{50}=187.02 \mu \mathrm{M}\right) \quad$ >aspartic acid $\left(\mathrm{IC}_{50}=202.301 \mu \mathrm{M}\right)>$ threonine $\left(\mathrm{IC}_{50}=211.498 \mu \mathrm{M}\right)>$ valine

Table 2 IC $_{50}$ values for amino acids and their oxovanadium (IV) complexes for $\alpha$-amylase inhibition

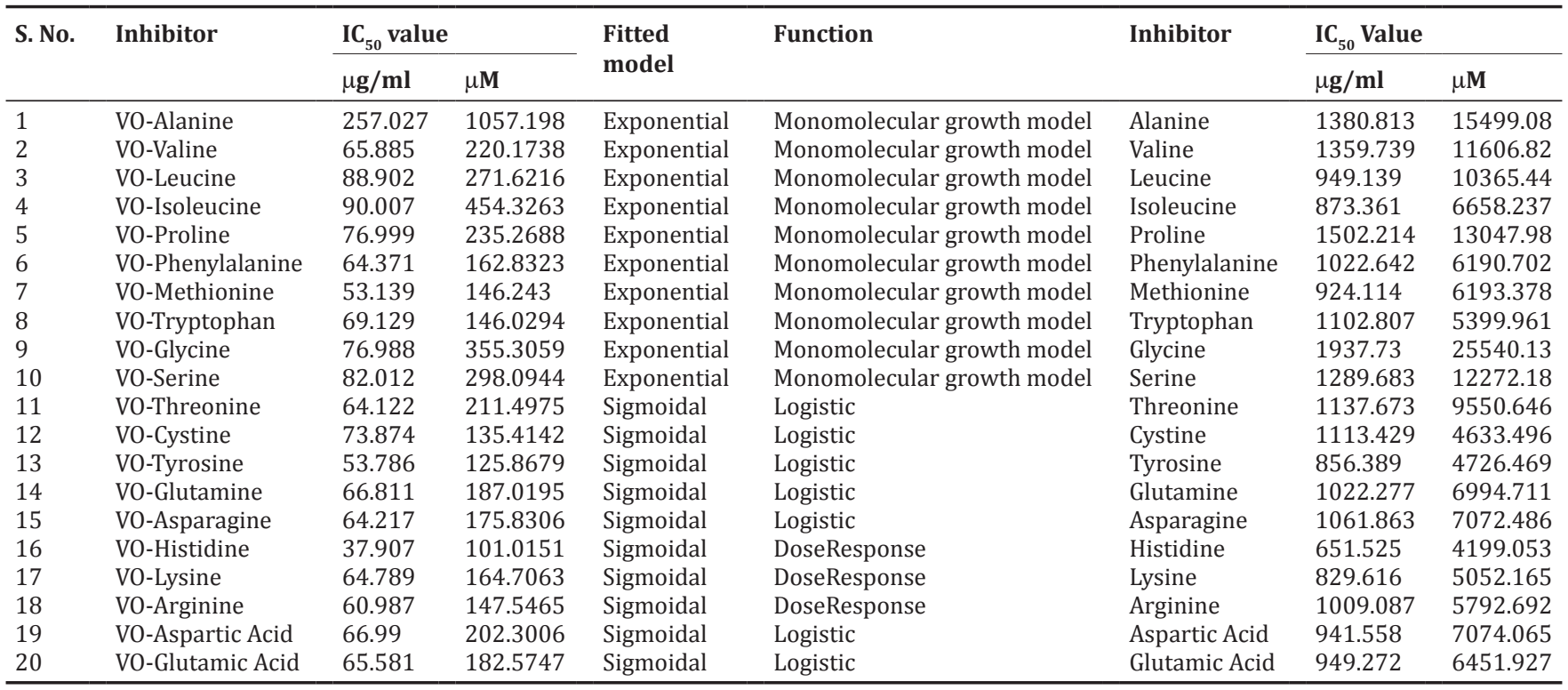




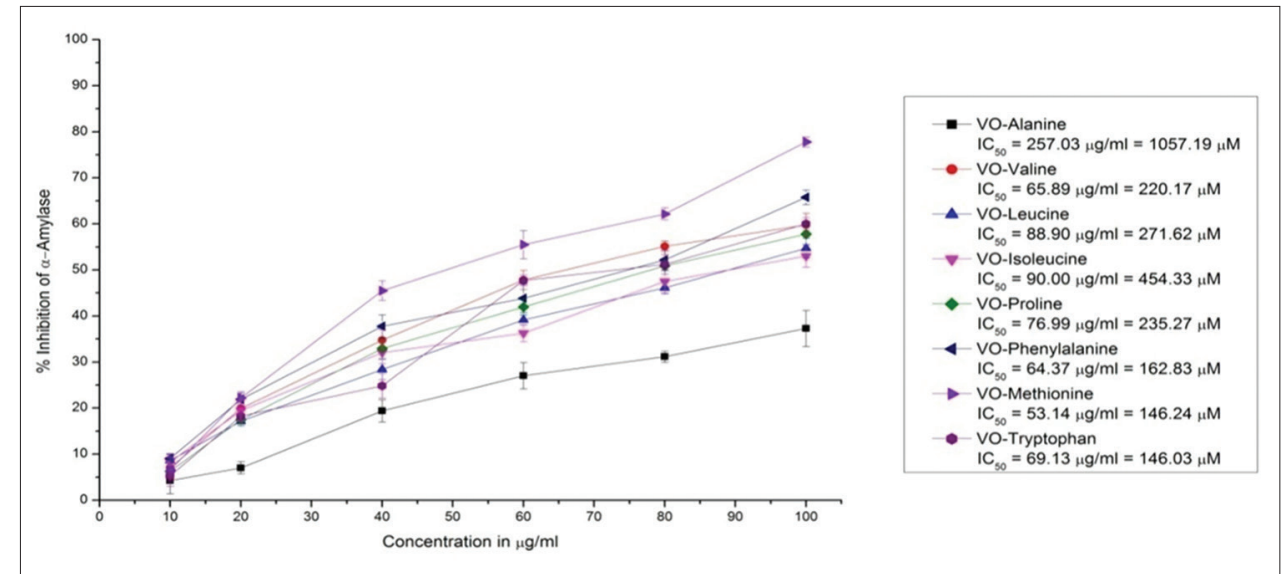

Fig. 2: Inhibition curve of oxovanadium (IV) complexes of Group A

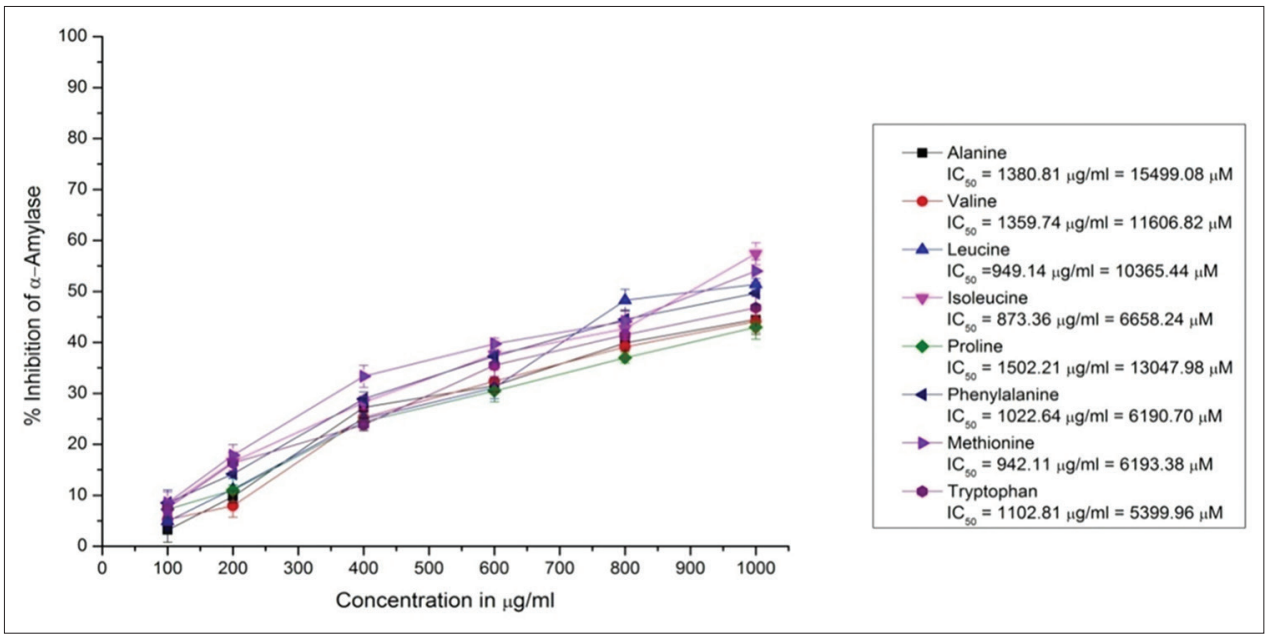

Fig. 3: Inhibition curve of amino acids of Group A

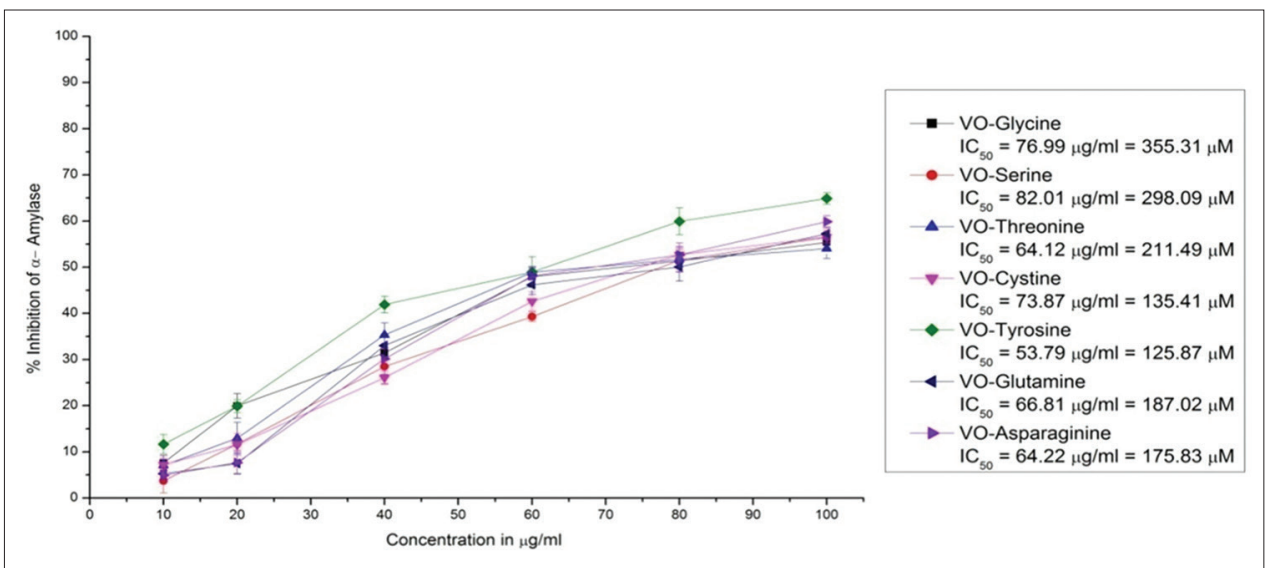

Fig. 4: Inhibition curve of oxovanadium (IV) complexes of Group B

$\left(\right.$ IC $\left._{50}=220.174 \mu \mathrm{M}\right)>$ proline $\left(\right.$ IC $\left._{50}=235.269 \mu \mathrm{M}\right)>$ leucine $\left(\mathrm{IC}_{50}=271.622\right.$ $\mu \mathrm{M})>$ serine $\left(\mathrm{IC}_{50}=298.094 \mu \mathrm{M}\right)>$ glycine $\left(\mathrm{IC}_{50}=355.306 \mu \mathrm{M}\right)>$ isoleucine $\left(\mathrm{IC}_{50}=454.326 \mu \mathrm{M}\right)>$ alanine $\left(\mathrm{IC}_{50}=1057.2 \mu \mathrm{M}\right)$.

\section{DISCUSSION}

Before the discovery of insulin in 1922 by Banting and Best French physicians Lyonnet et al. found that sodium metavanadate $\left(\mathrm{NaVO}_{3}\right)$ improved the state of human diabetic patients [20]. The modern era of studying the antidiabetic properties of vanadium was initiated in
1985 by John McNeill, who monitored the cardiac function of rats with streptozotocin -induced diabetes after treatment with Vanadyl sulfate, since then there are numerous biological activities have been studied to find the impact of inorganic and organic vanadium derivatives in induced diabetes animal models and in vitro assay system by various workers [21-24].

Amino acids are the building blocks of proteins found in structural tissues of the body. Amino acids are essential to life in free or polymeric 


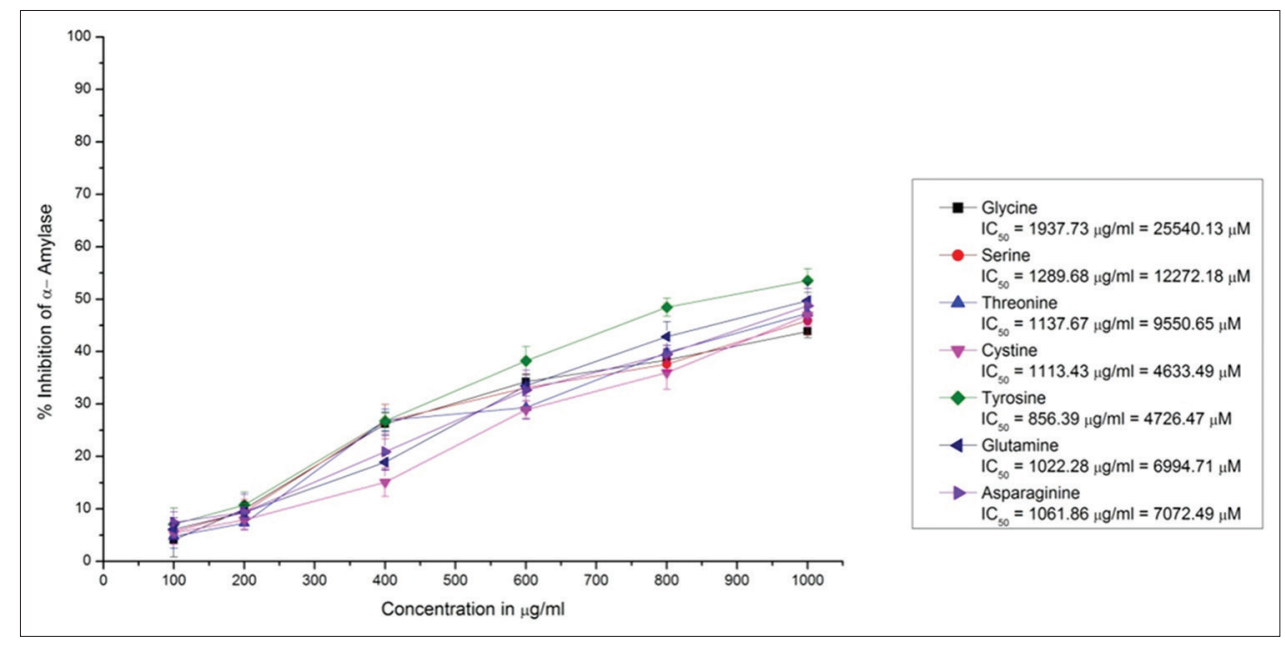

Fig. 5: Inhibition curve of amino acids of Group B

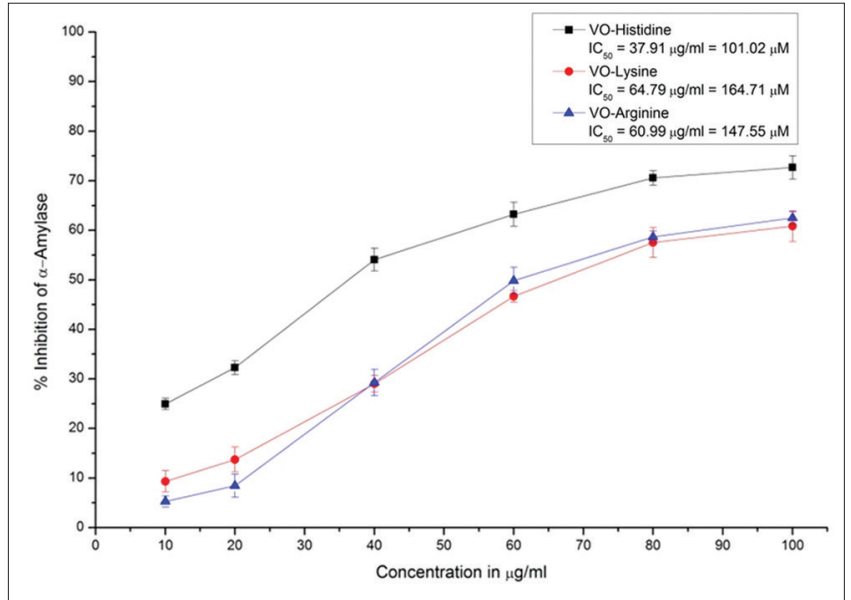

Fig. 6: Inhibition curve of oxovanadium (IV) complexes of Group C

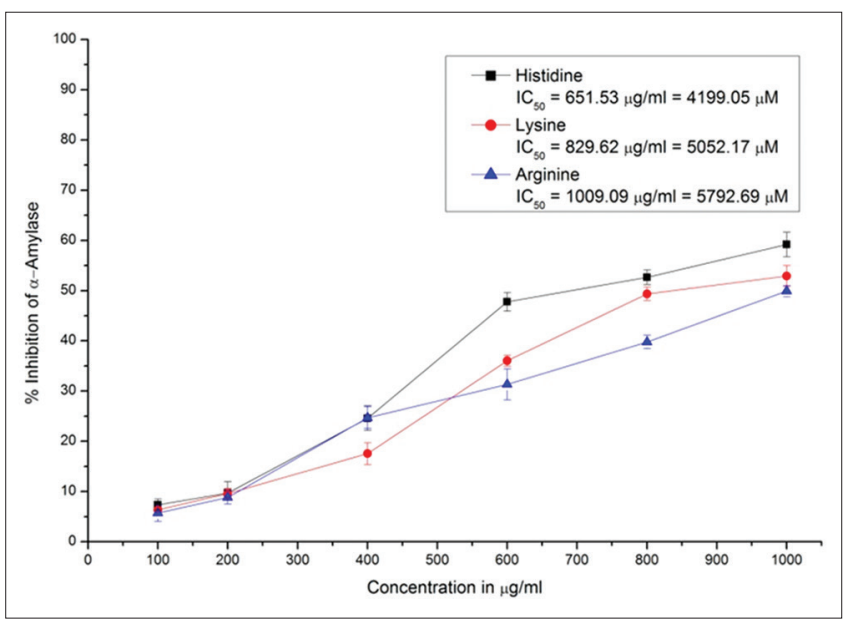

Fig. 7: Inhibition curve of amino acids of Group C

form as peptides. Amino acids play important roles in activities, such as neurotransmission, $\mathrm{pH}$ regulation, cholesterol metabolism, pain control, detoxification, and control of inflammatory response [25]. Some metabolic steps of amino acids related to vascular complications (methionine and arginine) exhibit a defective response to insulin in type-2 DM with nephropathy [26,27]. Obesity and insulin resistance are known to induce by proinflammatory in type 2 diabetes, together with

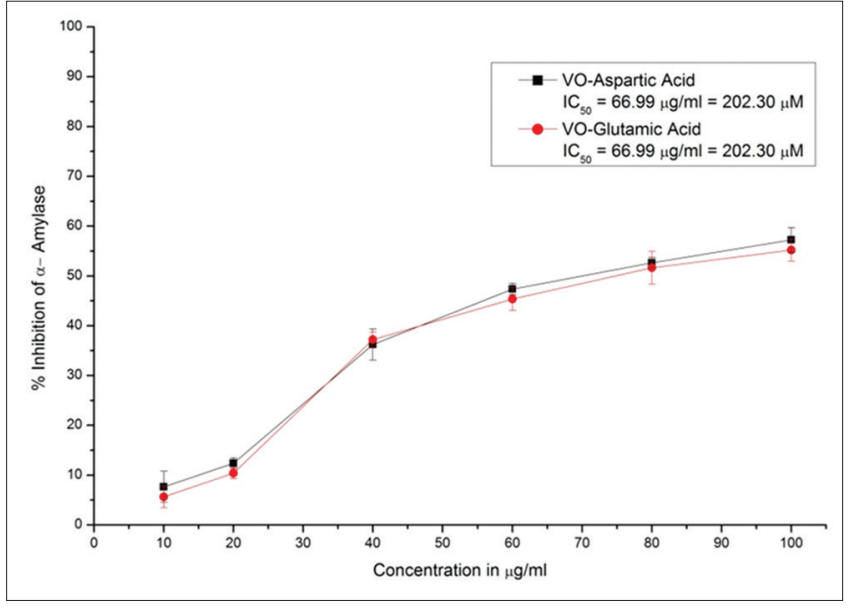

Fig. 8: Inhibition curve of oxovanadium (IV) complexes of Group D

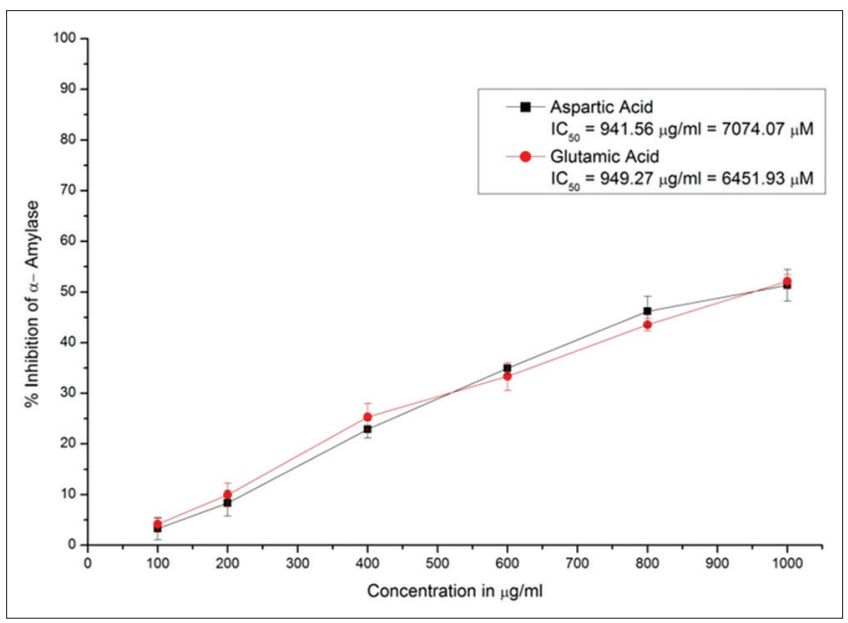

Fig. 9: Inhibition curve of amino acids of Group D

the cause adverse effects of hyperglycemia and hyperlipidemia and leads to the progressive dysfunction and demise of pancreatic $\beta$-cells. There are many workers reported that amino acids are also responsible for secretion of insulin and metabolism of glucose [27-30].

Therefore, we aimed to screen the inhibitory effect of l-amino acids and their respective oxovanadium (IV) complexes on $\alpha$-amylase. 


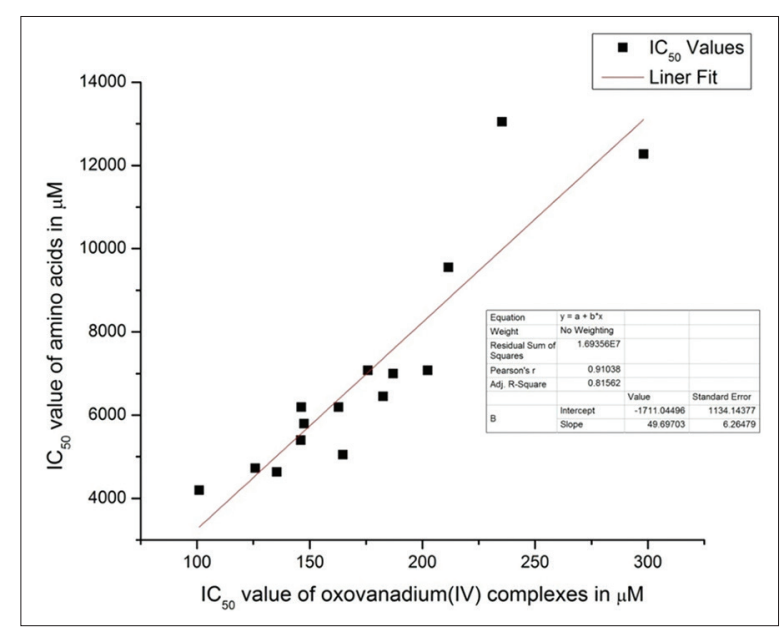

Fig. 10: Correlation plot of IC50 values $(\mu \mathrm{M})$ of amino acids and their oxovanadium (IV) complexes for $\alpha$-amylase

For the characterization of inhibitor (oxovanadium [IV] complexes), we have used cyclic voltammeter. The voltammetric method is satisfy many of the requirements for this analysis particularly because of voltammeter provide an idea about the state of oxidation of metal, rapid response, high sensitivity, low cost, simplicity, and relatively short analysis time. Misra et al. also reported that oxovanadium (IV) complexes have a vacant six coordinates which interact to the enzyme to inhibit their activity [34].

All the ligands (l-amino acids) of the present study fall into the category of the de melo Borges et al. [31] and contain phenyl, hydroxyl, imido, and carbonyl groups. Studies on structure-activity relationship on such compounds have shown that this carboxyl, hydroxyl, and amino groups are fundamental for their inhibition activity [32]. Madeswaran et al. studied computationally, interaction of the ligand/complex models generated after successful docking with $\alpha$-amylase and concluded that the parameters such as hydrogen bond interactions, $\Pi-\Pi$ interactions, binding energy, and play critical role by binding with active site residues with enzyme [33].

Oxovanadium (IV) complexes show much stronger $\alpha$-amylase inhibition compared to the corresponding ligands because, oxovanadium (IV) complex are of five coordinated. The sixth coordination of oxovanadium complex is vacant which bind to the enzyme [34,35]. Cornman et al. [35] have earlier suggested formation of such a bond between the metal ion and protein side chain for inhibition or activation of the enzymes. The inhibitors can be further stabilized in the active site through hydrogen bonds with catalytic residues and the establishment of hydrophobic contacts in a cooperative fashion. Further, workers suggest that $\alpha$-amylase can be inhibit, if inhibitor interact with 8 amino acids, with the enzyme binding site, which are Tyr-Gln-Ser-TrpArg-TyrSer-Gln [36-38].

\section{CONCLUSION}

The data obtained from cyclic voltammeter its appears all the oxovanadium(IV) complexes of l-amino acids are irreversible waves. The l-amino acids and their oxovanadium(IV) interact with $\alpha$-amylase to inhibit its catalytic activity. VO-Histidine and l-Histidine are most promising agents for inhibiting $\alpha$-amylase among all complexes and l-amino acids

\section{AUTHOR'S CONTRIBUTION}

All the authors contributed equally to planning, conductance of study, interpretation of results and writing.

\section{CONFLICTS OF INTEREST}

None of the authors have any conflicts of interest to declare.

\section{REFERENCES}

1. Henriksen EJ, Diamond-Stanic MK, Marchionne EM. Oxidative stress and the etiology of insulin resistance and Type 2 diabetes. Free Radic Biol Med 2010;51:993-9.

2. Gruenwald J, Freder J, Armbruester N. Cinnamon and health. Crit Rev Food Sci Nutr 2010;50:822-34

3. Adeghate E, Schattner P, Dunn E. An update on the etiology and epidemiology of diabetes mellitus. Ann N Y Acad Sci 2006;1084:1-29.

4. Kalsi A, Singh S, Taneja N, Kukal S, Mani S. Current treatments for Type 2 diabetes, their side effects and possible complementary treatments. Int J Pharm Pharm Sci 2015;7:14-8.

5. Smyth S, Heron A. Diabetes and obesity: The twin epidemics. Nat Med 2006;12:75-80.

6. Lee Y, Berglund ED, Yu X, Wang MY, Evans MR, Scherer PE, et al. Hyperglycemia in rodent models of Type 2 diabetes requires insulin resistant alpha cells. Proc Natl Acad Sci U S A 2014;111:13217-22.

7. Ramasubbu N, Paloth V, Luo Y, Brayer GD, Levine MJ. Structure of human salivary alpha-amylase at 1.6 a resolution: Implications for its role in the oral cavity. Acta Crystallogr Sect D Biol Crystallogr 1996;52:435-46.

8. Butterworth PJ, Warren FJ, Ellis PR. Human alpha-amylase and starch digestion: An interesting marriage. Starch J 2011;63:395-405.

9. Inzucchi SE, Bergenstal RM, Buse JB, Diamant M, Ferrannini E, Nauck M, et al. Management of hyperglycaemia in Type 2 diabetes, 2015: A patient-centred approach. Update to a position statement of the American diabetes association and the European association for the study of diabetes. Diabetologia 2015;58:429-42.

10. Nichols BL, Avery S, Sen P, Swallow DM, Hahn D, Sterchi E. The maltase-glucoamylase gene: Common ancestry to sucrase-isomaltase with complementary starch digestion activities. Proc Natl Acad Sci USA 2003;100:1432-7.

11. Sels JP, Huijberts MS, Wolffenbuttel BH. Miglitol, a new alphaglucosidase inhibitor. Expert Opin Pharmacother 1999;1:149-56.

12. Van de Laar FA. Alpha-glucosidase inhibitors in the early treatment of Type 2 diabetes. Vasc. Health Risk Manag 2008;4:1189-95.

13. Baron AD. Postprandial hyperglycaemia and alpha-glucosidase inhibitors. Diabetes Res Clin Pract 1998;40 Suppl:S51-5.

14. Panchal I, Sen DJ, Navle A, Shah U. Structure-based drug designing, scoring, and synthesis of some substituted sulphonylureas/guanidinebased derivatives as hypoglycemic agents. Int J Pharm Pharm Sci 2017;9:226-32.

15. Vichayanrat A, Ploybutr S, Tunlakit M, Watanakejorn P. Efficacy and safety of voglibose in comparison with acarbose in Type 2 diabetic patients. Diabetes Res Clin Pract 2002;55:99-103.

16. Pandeya KB, Tripathi IP, Mishra MM, Jaiswal N. Antiradical and antioxidant properties of some oxovanadium(IV) complexes of 1-amino acids. J Biol Sci Med 2016;2:38-47.

17. Boivin M, Flourie B, Rizza RA, Go VL, DiMagno EP. Gastrointestinal and metabolic effects of amylase inhibition in diabetics. Gastroenterology 1988;94:387-94.

18. Apostolidis E, Lee CM. In vitro potential of Ascophyllum nodosum phenolic antioxidant-mediated $\alpha$-glucosidase and $\alpha$-amylase inhibition. J Food Sci 2010;75:H97-H102.

19. Zou KH, Tuncali K, Silverman SG. Correlation and simple linear regression. Radiology 2003;227:617-28.

20. Lyonnet B, Martz M, Martin E. L'emploi therapeutique des derives du vanadium. La Presse Med 1899;1:191-2.

21. Willsky GR, Chi LH, Godzala M $3^{\text {rd }}$, Kostyniak PJ, Smee JJ, Trujillo AM, et al. Anti-diabetic effects of a series of vanadium dipicolinate complexes in rats with streptozotocin-induced diabetes. Coord Chem Rev 2011;255:2258-69.

22. Missaoui S, Rhouma KB, Yacoubi MT, Sakly M, Tebourbi O. Vanadyl sulfate Treatment stimulates proliferation and regeneration of beta cells in pancreatic islets. J Diabetes Res 2014;2014. DOI: $10.1155 / 2014 / 540242$

23. Thomas S, Jose AG, Quoc-Tuan D, Philippe B, Stefan L. Why antidiabetic vanadium complexes are not in the pipeline of "big pharma" drug research? a critical review. Curr Med Chem 2016;23:2874-91.

24. Adam AM, Naglah AM, Al-Omar MA, Refat MS. Synthesis of a new insulin-mimetic antidiabetic drug containing vitamin $\mathrm{A}$ and vanadium(IV) salt: Chemico-biological characterizations. Int $\mathrm{J}$ Immunopathol Pharmacol 2017;30:272-81.

25. Thompson MR. The role of amino acids in health and disease. Westchester Med Bull 1946;14:9-14.

26. Tessari P, Cecchet D, Cosma A, Puricelli L, Millioni R, Vedovato M, et al. Insulin resistance of amino acid and protein metabolism in Type 2 
diabetes. Clin Nutr 2011;30:267-72.

27. Al-Abbasi FA. Trend analysis of the correlation of amino acid plasma profile with glycemic status in Saudi diabetic patients. J Adv Res 2012;3:305-13.

28. van Loon LJ, Margriet K, Paul PC, Anton JM, Wim HM, Hans AK. Amino acid ingestion strongly enhances insulin secretion in patients with long-term Type 2 diabetes. Diabetes Care 2003;26:625-30.

29. Natarajan SK, Lakshmi S, Punitham R, Arokiasamy T, Sukumar B, Ramakrishnan S. Effect of oral supplementation of free amino acids in Type 2 diabetic patients--a pilot clinical trial. Med Sci Monit 2002;8:CR131-7.

30. Krause MS, McClenaghan NH, Flatt PR, de Bittencourt PI, Murphy C, Newsholme $\mathrm{P}$, et al. L-arginine is essential for pancreatic $\beta$-cell functional integrity, metabolism and defense from inflammatory challenge. J Endocrinol 2011;211:87-97.

31. de melo Borges E, Da Silvera Gomes A, Carvalho I. $\alpha$-and $\beta$-glucosidase inhibitors: Chemical structure and biological activity. Tetrahedron 2006;62:10277-302.

32. Niwa T, Doi U, Osawa T. Inhibitory activity of corn-derived bisamide compounds against alpha-glucosidase. J Agric Food Chem 2003;51:90-4.

33. Madeswaran A, Umamaheswari M, Asokkumar K, Sivashanmugam T, Subhadradevi V, Jagannath P. Computational drug discovery of potential TAU protein kinase I inhibitors using in silico docking studies. Bangladesh J Pharmacol 2013;8:131-5

34. Misra S, Pandeya KB, Tiwari A, Ali AZ, Saradamani T. $\alpha$-glucosidase inhibition and DPPH free radical scavenging by oxovanadium(IV) complexes of some tetradentate schiff bases. J Indian Chem Soc 2011;88:1195-201

35. Cornman CR, Zovinka EP, Meixner MH. Vanadium(IV) complexes of an active-site peptide of a protein tyrosine phosphate. Inorg Chem 1995;34:5099-100.

36. Ptlugrath JW, Wiegand G, Huber R, Vértesy L. Crystal structure determination, refinement and the molecular model of the $\alpha$-amylase inhibitor Hoe-467A. J Mol Biol 1986;189:383-6.

37. Kline AD, Braun W, Wuthrich K. Determination of the complete three dimensional structure of the $\alpha$-amylase inhibitor tendamistat in aqueous solution by nuclear magnetic resonance and distance Geometry. J Mol Biol 1988;204:675-724.

38. Wiegand G, Epp O, Huber R. The crystal structure of porcine pancreatic $\alpha$-amylase in complex with the microbial inhibitor tendamistat. J Mol Biol 1995;247:99-110. 